\title{
OFFICIAL RESPONSIBILITY AND PERSONAL RESPONSIBILITY IN THE CONTEXT OF STATE FINANCIAL LOSS
}

\author{
Hariyanto \\ Constitutional Law, Institut Agama Islam Negeri (IAIN) Purwokerto - Indonesia \\ Email: hariyanto_stainpwt@yahoo.com
}

\begin{abstract}
State financial Management which raises state's financial losses shows that there is a separation between official responsibilities and personal responsibility. The limits for determining the distinction of personal responsibility and official responsibilities when there is a state financial loss are the presence of mens rea (inner attitude and malicious intent) and maladministration. National Audit Board Report (LHP BPK) is used to determine the transition of official responsibilities into personal responsibilities in relation to the findings of unlawful acts, misuse of authority, opportunities or means available to them due to position. This is in line with the objective of settling the financial losses of the state from the legal aspects of state administration which emphasize the restoration of state financial losses, although the penalty can be cumulative with criminal, civil and administrative penalties.
\end{abstract}

Keywords: state finance, official responsibilities and personal responsibility, mens rea, maladministration

\begin{abstract}
Abstrak
Pengelolaan keuangan negara yang memunculkan kerugian keuangan negara dalam kajian yang mendalam ternyata menunjukkan bahwa terdapat pemisahan antara tanggung jawab jabatan dan tanggung jawab pribadi dari pejabat pemerintahan yang diberi kewenangan untuk mengelola keuangan negara. Batasan untuk menentukan pembedaan tanggung jawab pribadi dan tanggung jawab jabatan ketika terjadi kerugian keuangan negara adalah adanya mens rea (sikap batin dan niat jahat) dan maladministrasi. Laporan Hasil Pemeriksaan Badan Keuangan Negara (LHP BPK) digunakan untuk menentukan transisi/peralihan tanggung jawab jabatan (administrasi) menjadi tanggung jawab pribadi (pidana) berkaitan dengan adanya temuan perbuatan melawan hukum, menyalahgunaan wewenang, kesempatan atau sarana yang ada padanya karena jabatan atau kedudukan. Hal tersebut sejalan dan selaras dengan tujuan penyelesaian kerugian keuangan negara dari aspek hukum administrasi negara yang menekankan pada pemulihan kerugian keuangan negara, meskipun hukumannya bisa dikumulatifkan dengan hukuman pidana, perdata dan administrasi.
\end{abstract}

Kata kunci: keuangan negara, tanggung jawab pribadi dan jabatan, mens rea, maladministrasi

\section{Introduction}

State financial management plays an essential role in state organization. It functions to manifest economic growth, stability and also income distribution in order to achieve the goal of a state as mentioned in paragraph IV Constitution 1945. Therefore, refinement and reinforcement in state finance, especially in managing state finance is one focus in Indonesia. ${ }^{1}$

Holmes Sianturi, “Kedudukan Keuangan Daerah dalam Pengelolaan Dana Hibah dan Bantuan Sosial Berdasar-
It is interesting that the fact of trial in Constitution Court related to the case of testing Constitution Number 17 Year 2003 of State Finance can be traced down in Constitutional Court Expert Description Number: 48 and 62/ $\mathrm{PUU}-\mathrm{XI} / 201$. It reveals when presenting testimony in hearing by The Corruption Eradication Commission (KPK) that handling the criminal

kan Perspektif Keuangan Negara”, Jurnal Wawasan Yuridika, Vol. 1, No. 1, March 2017, Bandung: Sekolah Tinggi Hukum Bandung, p. 86-106 
acts by KPK since 2004 until 2012 shows that corruption criminal act related to implementation Article 2 and Article 3 of Corruption Act makes loss of state finance or economy more than $80 \%$ from all of the case that is handled by KPK in total 337 cases. $^{2}$

State financial loss is one of seven groups of corruption criminal act that is constructed by thirty types based on Law Number 31 Year 1999 on Corruption Eradication juncto Law number 20 Year 2001 on Change Law Number 31 Year 1999. Bibit S. Rianto stated the state financial loss is the first group out of seven groups of corruption. ${ }^{3}$

A recent data from Transparency International shows that Corruption Perception Index puts Indonesia in 90 rank with score 37 . Corruption Perception Index of Transparency International is based on survey and report from a wide variety of stake holder towards corruption in public sectors. The indicators cover transparency in bureaucracy, citizen involvement, freedom of media, independent justice and also information access how public budget is used. ${ }^{4}$ Data and fact above show that the important thing of framework to identify the accountability of state financial management.

The management of state finance that causes state financial losses can be best described as two sides of a coin that contains two impacts of punishment at once. On one side, state financial loss is in administrative state law field; on the other side, corruption is in the criminal law field. Thus, the significance of this article is to provide theoretical explanation related to punishment that should be given seen from its responsibility: administrative penalty or criminal penalty. In broader sense, this article is also useful for law upholder and law practitioners to understand and implement two-sided responsibility in state financial ma-

2 Hernold Ferry Makawimbang, 2015, Memahami dan Menghindari Perbuatan Merugikan Keuangan Negara Dalam Tindak Pidana Korupsi dan Pencucian Uang, Yogyakarta: Thafa Media, p 8.

3 Allan Peter Sandag, "Tanggung Jawab Pemerintah dalam Pengelolaan Keuangan Negara Menurut Undang-Undang No. 17 Tahun 2003", Jurnal Lex Administratum, Vol. III No. 8, Oktober 2015, p. 53 - 60.

$4 \quad$ lbid nagement: official responsibility and personal responsibility.

\section{Discussion}

Position, Authority, and Official Responsibility

In contexts of administrative state law, government action is done by government officer. Position is an institution of a specified work formed for a ling period to which duties and authorities are given. ${ }^{5}$ As a result, a position which is imposed by obligation allows to perform a law act. According to Johannes Suhardjana, authority is a right to govern by country or even government. Authority is a legal power that is based on the implemented law. ${ }^{6}$

Despite its tight relationship, position and officer have an entirely different standing in law, separated and implication of law which is different and separated as well. If Mr. $A$ is a governor, then Mr. A has two identities: Mr. A as a state function (Governor) and Mr. A as an individual. If Mr. A gives a decision, the decision is given in contexts of their position as a governor, not as an individual. ${ }^{7}$

The determination of duty and authority also considered in a position. It will be the measure whether the duty must be run as well or not. When the rights and duty do not run as expected, it is because of an action ${ }^{1}$ that over the authority (detournemen de pouvoir) or the misuse of authority (misbruik van recht/abuse of power). As a legal subject, government is able to run any action either real or legal. The real action is the irrelevant action towards the law and it does not make any legal conse-

5 Retno Murni Sari, "Rencana Anggaran Keuangan Daerah Basis Konsep Peran Akuntansi Sektor Publik (Studi Pada Pemda Kabupaten Tulungagung)", Jurnal Kompilek Vol. 8 No. 1 Juni 2016, Blitar: Sekolah Tinggi Ilmu Ekonomi Kesuma Negara Blitar, p. 1-7

6 Johannes Suhardjana, 2003, Wewenang Kabupaten Dalam Pembangunan Perumahan, Disertasi, Surabaya: Program Pascasarjana Universitas Airlangga, p. 108.

7 Abdullah Ramdhani and Muhammad Ali Ramdhani, "Konsep Umum Pelaksanaan Kebijakan Publik", Jurnal Publik, Vol. 11 No. 1, 2017; p. 1-12 
quences, while the legal action is the action that can cause the legal consequences. ${ }^{8}$

Based on what mentioned above, there are some elements of government law action, they are: ${ }^{9}$ first, the action run by the government suited its position, the ruler or as the set of government, with the initiative and the responsibility. Second, the action is intended for running the function of government. Third, the intent of the action is a form of the access to affect the legal consequence of state administration. Fourth, the action is performed in order to maintain the importance of state and its people. Fifth, the action must be based on the legislation.

If the government legal action does not have the legislation as the guidance, it is called as onbevoeged. The scopes of onbevoeged itself are: ${ }^{10}$ first, the absolute incompetentie. It relates to the substance of authority or a matter about attribution, delegates, and mandate. Second, relatieve incompetentie. The relatieve incompetentie relates to the time and place. For example, the territorial deconstruction (not the city $A$ but the city $B$ who has the authority) or relates to the deconstruction of the apparatus workers of central government (e.g. the city that must be checked is city A not B).

Onbevoeged can happen when: ${ }^{11}$ first, it does not have territory authority (onbevoegdheid rational loci or onbevoegdheid naar plaats). Second, it does not have temporal authority (onbevoegdheid rational temporis or onbevoegdheid naar tijd). Third, it does not have material authority (onbevoegdheid rational materie or onbevoegdheid naar materie).

Seeing from the legality, the officer acts cover three factors; first, authority. Every act performed by government officers must be based on the legal authority. Moreover, the authority can be reached by three aspects; Attribution, Delegates, and Mandate. Second, procedure. After holding the authority to act, the

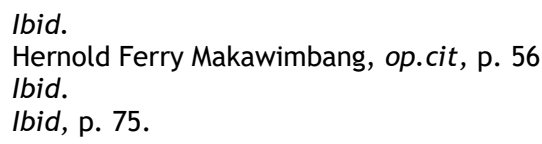

officers must obey the base of the procedure, they are; The Principle of Law State, Democracy Principle, and Instrumentality principle. Third, substance. The government authority (government officials) to manage and control the living of people is limited by the substance. For instance, the authority to put Property Tax. It is substantially determined and measured based on land and building width not based on what inside the building. The substantial aspect is about what and what for. The substantial flaw about what" is related to the arbitrary act and the substantial flaw about what for is related to the authority misuse.

\section{Official Responsibility of State Financial Ma- nagement}

The quality of government officers act is influenced by the officer's personality. However, the official responsibility they have will always attach to them. The time of giving the authority to the government officers is also the time to report on how the responsibility of the officers itself. Accordingly, in Administrative Law, the official responsibility and personal responsibility is different.

The official responsibility relates to the legality of government act. In Administrative Law, the legality of government act is related to the approach towards the government authority while the personal responsibility relates to the functionary approach or behavior approach in Administrative Law. Besides, the personal responsibility also linked to maladministration in using the authority. The comparison between official responsibility and personal responsibility is shown in table $1 .^{12}$

Considering the explanation above, there is a separation of official responsibility and personal responsibility related to financial loss in State Financial management by state officials. The two distinguishing factors are first, presence or absence of maladministration and second,

12 Marcus Lukman, "Penggeseran Tanggung Jawab Tindak Hukum Administrasi Ke Tindak Pidana Korupsi Dalam Kasus Diskresi Hukum Pejabat Tata Usaha Negara", Jurnal Perspektif Volum X Number.2 Year 2010, Surabaya: Universitas Wijaya Kusuma Surabaya, page.117 
Table 1. The comparison between the responsibility of position and the personal responsibility.

\begin{tabular}{|c|c|}
\hline Official Responsibility & Personal Responsibility \\
\hline $\begin{array}{l}\text { Focus on: the legality of act } \\
\text { - Authority } \\
\text { - Procedure } \\
\text { - Substance }\end{array}$ & $\begin{array}{l}\text { Focus on: } \\
\text { Maladministration of apparatus bad behaviour/contempt } \\
\text { of court on implementing the duty, shown by; } \\
\text { - Arbitrary } \\
\text { - Misuse of authority }\end{array}$ \\
\hline $\begin{array}{l}\text { Parameter: } \\
\text { - Legislation } \\
\text { - The right general principle }\end{array}$ & $\begin{array}{l}\text { Parameter: } \\
\text { - Legislation } \\
\text { - The right general principle } \\
\text { - Code of good administrative behavior (Uni Europe) }\end{array}$ \\
\hline $\begin{array}{l}\text { Juridical Question; } \\
\text { Is there any Juridical flaw about: } \\
\text { - Authority } \\
\text { - Procedure } \\
\text { - Substance }\end{array}$ & $\begin{array}{l}\text { Juridical Question; } \\
\text { Is there any maladministration in that kind of act }\end{array}$ \\
\hline $\begin{array}{l}\text { No mens rea (bad intent) from officials } \\
\text { government }\end{array}$ & There is mens rea \\
\hline $\begin{array}{l}\text { The praesumption iuste causta principle; } \\
\text { Every government act must be considered } \\
\text { as legal unless there is a cancellation or } \\
\text { defense }\end{array}$ & Related to criminal; presumption of innocence \\
\hline Vicatoius liability principle: Valid & Vicatoius liability principle: Invalidate \\
\hline Sanction: administrative and civil sanction & Sanksi: administrative, civil, and criminal sanction \\
\hline
\end{tabular}

presence or absence of mens rea. ${ }^{13}$ To determine whether a state officials commit corruption (criminal liability) can be seen: ${ }^{14}$ from the abuse of power (detournement de pouvoir), the arbitrary (willekeur) and the act beyond the power (Ultra vires).

The writers propose that the administrative abuse is the main determiner or the first entrance for detection if what they do belong to official responsibility or not. In other words, the separation of official and personal responsibility is firstly identified by the presence or absence of maladministration. Detecting maladministration can be done through abuse of power (detournement de pouvoir) and the arbitrary (willekeur) and also tested with the parameters of the general principles of the best government (algemene beginselen van behookrijk bestuur) which is then subsequently specified into acts against law, authority misuse, a chance or tools that exist on that because of

13 Indrawati, "Prinsip Good Financial Governance dalam Pengelolaan Keuangan Negara dalam Rangka Mewujudkan Clean Governance", Jurnal Perspektif, Vol XVII No. 3, September 2012, p. 201.

14 Hernold Ferry Makawimbang, op.cit, p. 84 position and ranking, potentially state financial loss. ${ }^{15}$

The next is investigators (e.g. Police, Indonesia's Corruption Eradication Commission and attorney office) that will search and investigate: the presence of mens rea (bad intention), for instance, motive or the intention to enrich themselves, the other, their community or their corporation/company.

National Audit Board Reports as a Measurement to Determine the Official Responsibilities and Personal Responsibilities

Reports of National Audit Board includes financial audit, performance audit and particular audit for specific purposes of which the final result stating whether an governmental institution conducts corruption which loses state finance or not. The report contains four opinions that can be given by supervisor in the name of National Audit Board: first, the best opinion

15 Ezra Paula Mentu and Jullie J. Sondakh, "Penyajian Laporan Keuangan Daerah Sesuai Peraturan Pemerintah No. 71 Tahun 2010 Tentang Standar Akuntansi Pemerintahan Pada Dinas Pendapatan Daerah Dan Dinas Sosial Prov. Sulut”, Jurnal EMBA, Vol. 4 No. 1, Maret 2016, p. 1392-1399. 
is Unqualified Opinion; second, the second best opinion is Qualified Opinion; third, the worst opinion is Adverse Opinion; forth, is Disclaimer Opinion. ${ }^{16}$

The Evaluation Report of National Audit Board which indicates the occurrence of state financial losses and causes accountability in administration is Qualified Opinion. This audit is given because, despite its potential mistake, it did not affect the rationality of report. Meanwhile, the audit report which indicates the occurrence of state financial losses and causes accountability in crime is Adverse Opinion. This is given because the auditor convince, based on the evidences, that there are many incorrect materials in the evaluation report. It means the evaluation report did not depict the financial condition correctly and many indications of administrative fault. ${ }^{17}$

Thus, the National Audit Board report is the main instrument to know whether the officials action in managing the state finance lose the state finance or not. It can also be used to identify separation of official responsibility and personal responsibility.

Although the result of The Evaluation Report of National Audit Board is administrative and not Pro Justitia, it can identify the maladministration which leads to corruption. This corresponds to Article 187 Law of Criminal Code Procedures that The Evaluation Report of National Audit Board is categorized as evidence that can be used by investigators (Police, Corruption Eradication Commission, and Attorney) and will be presented in the court. In the meantime, from the perspective of Administrative Law and Constitutional Law, it is clear that legitimate State Institution and has legal standing for doing investigation at state financial management is National Audit Board, as a re-

16 A.P. Edi Atmaja, "Penyelesaian Kerugian Daerah Melalui Penyetoran Ke Kas Negara: Suatu Kajian Hukum Doktrinal”, Jurnal Tata Kelola \& Akuntabilitas Keuangan Negara, Vol 3 No. 2, July-December 2017, p. 169181.

17 Kukuh Tejomurti, “Pertanggungjawaban Hukum yang Berkeadilan terhadap Aparatur Pemerintah pada Kasus Pengadaang Barang dan Jasa", Jurnal Dialogia luridica, Volume 8 No.2, April 2017, Bandung, Law Faculty of Kristen Maranatha, p. 42-52 sult, The Evaluation Report of National Audit is not only valid as evidence but also legitimate constitutional value. ${ }^{18}$

This is in line with the concept that the settlement of state financial losses in the dimensions of the State Administration Law is principally oriented towards the restoration of the country's financial losses, although it may be applied cumulatively with other sanctions: criminal sanctions, administration and civil administration. This has been conceived in Law No. 17 of 2003 on State Finance Article 34, 35 and also in Law No. 1 of 2004 on State Treasury Article 59, 60, 61, 62, 63, 64, 66 and 67.

The National Audit Board Report in order to determine the level of sanctions/penalties in the context of state financial management has the following functions: first, indicator of state financial losses; secondly, determining the transition/transfer of official responsibilities (administration) to personal (criminal) responsibility in relation to the findings of unlawful acts, misuse of authority, opportunity or means available to him by title or position.

In the investigation and prosecution process, the Audit Report can be used as a starting point to separate official responsibilities from personal responsibilities. Therefore, it will be easier to identify and construct elements of the country's financial losses whether they deemed under the category of corruption or category of administration.

\section{Conclusion}

The state financial management that causes financial losses has legal implications of personal responsibility and official responsibilities. The official responsibilities relate to the legality (legitimacy) of governmental acts while personal responsibilities relate to a functional approach or behavioral approach in administrative law. There is a separation of personal res-

18 Mieke Rayu Raba, “Peran Badan Pemeriksa Keuangan (BPK) dalam Melakukan Pemeriksaan terhadap Pengelolaan Keuangan Negara untuk Mewujudkan Pemerintahan yang Baik Menurut UU No. 15 Tahun 2006", Jurnal Lex Crime Vol. VI/No. 3/Mei/2017, Manado: Bagian Hukum Pidana Fakultas Hukum Universitas Sam Ratulangi Manado, hlm. 152 
ponsibility and official responsibilities in relation to losses in state financial management by government officials. Two elements or factors that clearly become the separator and distinguishing factors are maladministration and the presence of mens rea.

The Nattional Audit Board Report is used as an indicator, not only to detect any state financial loss in the context of state financial management, but also to determine the transition/transition the official responsibility (administration) to personal (criminal) responsibility in relation to the findings of unlawful acts, misuse of authority, opportunity or means available to him due to any position. This is in line with the concept that the settlement of state financial losses in the dimensions of the State Administration Law principally oriented towards the restoration of the country's financial losses, although it may be applied cumulatively with other sanctions: criminal sanctions, administration and civil.

\section{References}

Atmaja, A.P. Edi. "Penyelesaian Kerugian Daerah Melalui Penyetoran Ke Kas Negara: Suatu Kajian Hukum Doktrinal". Jurnal Tata Kelola \& Akuntabilitas Keuangan Negara Vol. 3 No. 2. JulyDecember 2017. Pp. 169-182. DOI; http://dx.doi.org/10.28986/jtaken. v3i2.85;

Indrawati. "Prinsip Good Financial Governance dalam Pengelolaan Keuangan Negara dalam Rangka Mewujudkan Clean Governance". Jurnal Perspektif. Vol XVII No. 3. September 2012. Pp. 201-212

Lukman, Marcus. "Penggeseran Tanggung Jawab Tindak Hukum Administrasi Ke Tindak Pidana Korupsi Dalam Kasus Diskresi Hukum Pejabat Tata Usaha Negara”. Jurnal Perspektif. Vol. X No. 2. March 2010. Pp. 177- 194;

Makawimbang, Hernold Ferry. 2015. Memahami dan Menghindari Perbuatan Merugikan Keuangan Negara Dalam Tindak Pidana Korupsi dan Pencucian Uang. Yogyakarta: Thafa Media;

Mentu, Ezra Paula and Jullie J. Sondakh. "Penyajian Laporan Keuangan Daerah
Sesuai Peraturan Pemerintah No.71 Tahun 2010 Tentang Standar Akuntansi Pemerintahan pada Dinas Pendapatan Daerah dan Dinas Sosial Prov. Sulut". Jurnal EMBA. Vol. 4 No. 1. March 2016. Pp. 1391-1399;

Raba, Mieke Rayu. "Peran Badan Pemeriksa Keuangan (BPK) dalam Melakukan Pemeriksaan Terhadap Pengelolaan Keuangan Negara untuk Mewujudkan Pemerintahan Yang Baik Menurut UU No. 15 Tahun 2006". Jurnal Lex Crime. Vol. VI No. 3. May 2017. Pp. 152-160;

Ramdhani, Abdullah and Muhammad Ali Ramdhani. "Konsep Umum Pelaksanaan Kebijakan Publik". Jurnal Publik. Vol. 11 No. 01; Januari 2017. Pp. 112 ;

Ridwan. 2010. Hukum Administrasi Negara, Jakarta: Raja Grafindo Persada;

Sandag, Allan Peter. "Tanggung Jawab Pemerintah Dalam Pengelolaan Keuangan Negara Menurut Undang-Undang No. 17 Tahun 2003". Jurnal Lex Administratum. Vol. III No. 8. October 2015. Pp. 53-60;

Sari, Retno Murni. “Rencana Anggaran Keuangan Daerah Basis Konsep Peran Akuntansi Sektor Publik (Studi Pada Pemda Kabupaten Tulungagung)". Jurnal Kompilek. Vol. 8 No. 1. June 2016. Pp. 1-7;

Sianturi, Holmes. “Kedudukan Keuangan Daerah Dalam Pengelolaan Dana Hibah Dan Bantuan Sosial Berdasarkan Perspektif Keuangan Negara”. Jurnal Wawasan Yuridika. Vol. 1 No. 1, March 2017. Pp 86-106. DOI: 10.25072/jwy. v1i1.129;

Suhardjana, Johannes. 2003. Wewenang Kabupaten dalam Pembangunan Perumahan. Disertasi. Surabaya: Program Pasca-sarjana Universitas Airlangga;

Tejomurti, Kukuh. 2017. "Pertanggungjawaban Hukum yang Berkeadilan terhadap Aparatur Pemerintah pada Kasus Pengadaan Barang dan Jasa". Jurnal Dialogia luridica. Vol. 8 No. 2. April 2017. Pp. 42-52. 